\title{
The state of Scapania ligulata Steph. (Scapaniaceae, Marchantiophyta) in Western Himalaya, India
}

\author{
Meena Rai, Bishwajit K. Kushwaha and Surendra N. Srivastava* \\ Department of Botany, C.M.P. College, Allahabad 211 002, Uttar Pradesh, India \\ Article history \\ Received: 14 August 2015 \\ Accepted: 10 September 2015 \\ Published online: 1 October 2015 \\ (C) Rai et al. (2015) \\ Editors \\ Afroz Alam

\begin{abstract}
The two subspecies of the leafy liverwort, Scapania ligulata Steph., namely, subsp. ligulata and subsp. stephanii (Mull Frib.) Potemkin, Piippo \& T.J. Kop., collected from the Kumaun and adjacent region in Western Himalaya, India are being described and compared. The report of the presence of the subspecies stephanii in this region confirms the fact that the ligulata-stephanii species complex having both subspecies migrated to Himalaya. The paper provides some additional distinctive features between the two subspecies.
\end{abstract}

Dipjyoti Chakraborty

Publisher

Horizon e-Publishing Group

Corresponding Author

Meena Rai

吕meena@yahoo.co.in

\author{
Keywords \\ Scapania; Leafy liverwort; Kumaun; Western Himalaya; ligulata-stephanii complex
}

Rai, M., Kushwaha, B. K. and Srivastava, S. N. 2015. The state of Scapania ligulata Steph. (Scapaniaceae, Marchantiophyta) in Western Himalaya, India. Plant Science Today 2(4): 197202. http://dx.doi.org/10.14719/pst.2015.2.4.141

\section{Introduction}

In course of survey of the liverwort flora of Kumaun region and adjoining areas, located in Uttarakhand state of Western Himalaya, we recently came across some populations of an interesting species of Scapania (Dumort.) Dumort. at Gwaldam $\left(79.56^{\circ} \mathrm{E} ; 30.00^{\circ} \mathrm{N}\right.$; alt. $1882 \mathrm{~m})$. The population had all the shades ranging between green to reddish brown and were rhizomatous in nature. A closure examination of the specimens suggested these to be $S$. ligulata subsp. stephanii (Müll Frib.) Potemkin, Piippo \& T. J. Kop. A perusal of literature on the occurrence of this species in Western Himalaya revealed that Srivastava \& Srivastava (2007) had described a taxon, namely, S. stephanii K. Müll. and an 'ecotype' from Champawat $\left(80.08^{\circ} \mathrm{E} ; 29.40^{\circ} \mathrm{N}\right.$; alt. $\left.1649 \mathrm{~m}\right)$ in Kumaun region. On the basis of closer similarities, S. stephanii K. Müll. had often been considered a synonym of S. ligulata Steph. However, recently Potemkin et al. (2004), based on their observations, segregated the ligulata-stephani complex into two subspecies. In the light of this development, the issue remained unresolved as to which of the two subspecies the Champawat specimens belonged? Therefore, the herbarium specimens of Champawat, described by Srivastava \& Srivastava (2007), were also critically examined and revalued in the present study: and, the subspecies described by them subsequentally turned out to be that of S. ligulata Steph. subsp. ligulata and its'ecotype' as S. ligulata subsp. stephanii (Müll Frib.) Potemkin, Piippo \& T. J. Kop.

As the situation stands today, both the subspecies namely $S$. ligulata subsp. ligulata and S. ligulata subsp. stephanii are now known from the Kumaun region and adjacent areas in Western Himalaya in India (Plate 1).

The two taxa may be separated as follows:

Plants smaller, 8 to $13 \mathrm{~mm}$ long, green to reddish brown; stem cortex in 2 - 3 layers; leaf - lobes triangularly ovate with a distinct pointed tip, marginal teeth absent or $1-2$ indistinctly present; gemmae largely unicellular -S. ligulata subsp. stephanii 
Plants larger, 10 to $30 \mathrm{~mm}$ long, dark brown; stem cortex in 3 - 4 layers; leaf - lobes broader and obtuse to subacuminate, marginal teeth rather common; gemmae 2-(1) celled S. ligulata subsp. ligulata

With the inclusion of the two sub species of $\mathrm{S}$. ligulata Steph.the total number of Scapania taxa in the Western Himalaya becomes twelve (Kashyap 1932; Srivastava \& Srivastava 1993; Parihar et al. 1994; Srivastava \& Srivastava 1995; Dandotiya et al. 2007; Srivastava \& Srivastava 2007; Singh \& Singh 2009). These include: $S$. aequiloba (Schwaegr.) Dumort.,S. ferruginea (Lehm. \& Lindenb.) Gottsche et al., S. glaucocephala (Taylor) Austin, S. griffithi Schiffn., S. orientalis Steph., S. parva Steph., $S$. purpurea Kash., S. stephanii K. Müll. (S. ligulata Steph. subsp. ligulata), S. ligulata Steph. subsp. stephanii (Müll Frib.) Potemkin, Piippo \& T. J. Kop., S. udarii Srivastava \& Srivastava, S. undulata (L.) Dumort, and $S$. verrucosa Heeg.

The paper describes the two taxa collected from the Kumaun and adjacent region in the Western Himalaya, submits an ecological note and discusses their probable radiation.

\section{Materials and Methods}

The morphological studies of both fresh and herbarium specimens were made using Motic BA 210 Digital microscope. The slides of various plant parts including hand sections were mounted in glycerine jelly. The field photographs were taken by Olympus camera. All the specimens are deposited in Duthie Herbarium, Botany Department, University of Allahabad.

\section{Description \\ Scapania ligulata subsp. stephanii (Mull Frib.) Potemkin, Piippo \& T. J. Kop.}

Ann.Bot. Fennici 41:423 (2004); Scapania stephanii C. Muell, Nova Acta Acad. Caes. Leop.-Carol, German Nat. Cur. 83:273 (1905); Amakawa \& Hattori, Journ. Hattori Bot. Lab. 12: 96 (1954). (Plate 2: Figures A-L).

Plants small, 8 to $13 \mathrm{~mm}$ long, 1.5 to $3.0 \mathrm{~mm}$ wide with leaves, green to reddish brown, in tufts, arising from a dark brown to blackish creeping rhizomatous portion. Stem $0.18-0.3 \mathrm{~mm}$ wide, rigid, brown, ascending, simple or sparingly branched, branches intercalary; in cross section the cortex and medulla well differentiated, the cortical cells in 2 to 3 layers, $10-12 \times 12-20 \mu \mathrm{m}$, dark to light brown, walls as thick as or thicker than the radial diameter of cell cavity, medullary cells larger, 20-28 x 12-20 $\mu \mathrm{m}$,thin-walled, pale to white. Rhizoides numerous, long, colourless, confined to rhizomatous portion only. Leaves much smaller near the base but gradually becoming larger towards the apex of the stem, all leaves in a plant may be green, reddish brown or a mix of the two colours with upper leaves turning brown first, 8 to 12 pairs, distant but imbricate towards the stem apex, widely spreading and and unequally bilobed. Keel short, 0.2 to $0.5 \mathrm{~mm}$ long, about $1 / 4.5$ of the leaflobule, dorsally somewhat concave, 2 to 3 celled thick. Leaf-lobe appressed to stem, triangularly ovate, arching halfway or more the stem width, nearly transversely inserted, not decurrent, $0.4-0.6 \mathrm{~mm}$ long and $0.35-0.5 \mathrm{~mm}$ wide, 0.35 of the length of the leaf-lobule, acuminate with a sharply pointed tip, margin smooth or with a few undulations but never denticulate. Leaf-lobule ligulate, $1.14-1.75 \mathrm{~mm}$ long, $0.7-1.2 \mathrm{~mm}$ wide (about $1.5 / 1$ as long as wide, the line of insertion arcuate upwards on the stem and ending below the keel, decurrent, apex subacute to obtuse, margin minutely to coarsely dentate, teeth variable, $1-3$ cells in height to $1-3$ cells in width. Marginal cells of the leaf $10-20 \times 10-17 \mu \mathrm{m}$, equally thickened; median cells13 - 24 x 13 - $20 \mu \mathrm{m}$; basal cells $20-30 \times 12-24 \mu \mathrm{m}$, walls thin, trigones distinct, slightly to moderately bulging, cuticle nearly smooth; Oil-bodies, oval to spherical $2-4$ per cell, large $9 \times 5$ $\mu \mathrm{m}$. Gemmae 1 - celled, ovate with a broader base, 15 - 22 × $10-16 \mu \mathrm{m}$, produced in branching fascicles from the marginal and even submarginal cells of the youngest leaves, whitish green, each gemma with 1 4 oil-bodies.

\section{Specimens examined}

India, Western Himalaya, State of Uttarakhand, Kumaun \& adjacent region (i) District Chamoli, Gwaldam: WHKB 0207 L/14, WHKB 0208 L/14, March 2014, leg. S. N. Srivastava \& party, det. M Rai et al. (ii) District Champawat, Mayavati in Lohaghat (alt.1950 meters), 460, September 1977.Deposited in the Duthie Herbarium of the Botany Department, University of Allahabad.

\section{Ecology \& Distribution}

The Gwaldum populations were growing on the exposed vertical cliffs of the roadside along with the thalli of Targionia hypophylla and some pleurocarpous mosses; whereas the Lohaghat populations were growing under rather not so exposed sites. At both locations it was an oak (Quercus leucotrichophora) dominated forest.

\section{Scapania ligulata Steph. subsp. ligulata}

Hedwigia 44:14 (1904); Amakawa, Journ. Hattori Bot. Lab. 27:15 (1964); S. stephanii K. Muell., Srivastava \& Srivastava, Phytomorphology 57(3):134 (2007) (Plate 3: Figures A-J)

Plants medium-sized, brownish red. Stem 10-30 $\mathrm{mm}$ long and $0.18-0.30 \mathrm{~mm}$ in diameter, with leaves 2.5-3.0 mm wide, ascending to erect, simple or sparingly branched, brown or red, sometimes green; in cross-section, the cortex and medulla welldifferentiated, cortical cells in 3-4 layers, brown, 6-9 $\mu \mathrm{m}$, walls thick as cell cavities, often bast-fiber like, medullary cells, white, 14-18 $\mu \mathrm{m}$, thin-walled. Rhizoids numerous. Leaves rather larger near the stem tip, keel rather short, 3/10-4/10 the length of leaf-lobule, slightly concave on dorsal side, wings often distinct; the leaf-lobe nearly transversely inserted, not decurrent, appressed to the stem, rectangular to ovate, about 3/5 the length of leaflobule, 0.7-1.1 $\mathrm{mm}$ long and 0.6-0.9 mm wide, arching to the middle of the stem up to its farther edge, apex subacute with a point or obtuse, margin denticulate to dentate, teeth unicellular to multicellular; the leaf-lobule nearly transversely inserted with the line of insertion curved upwards 


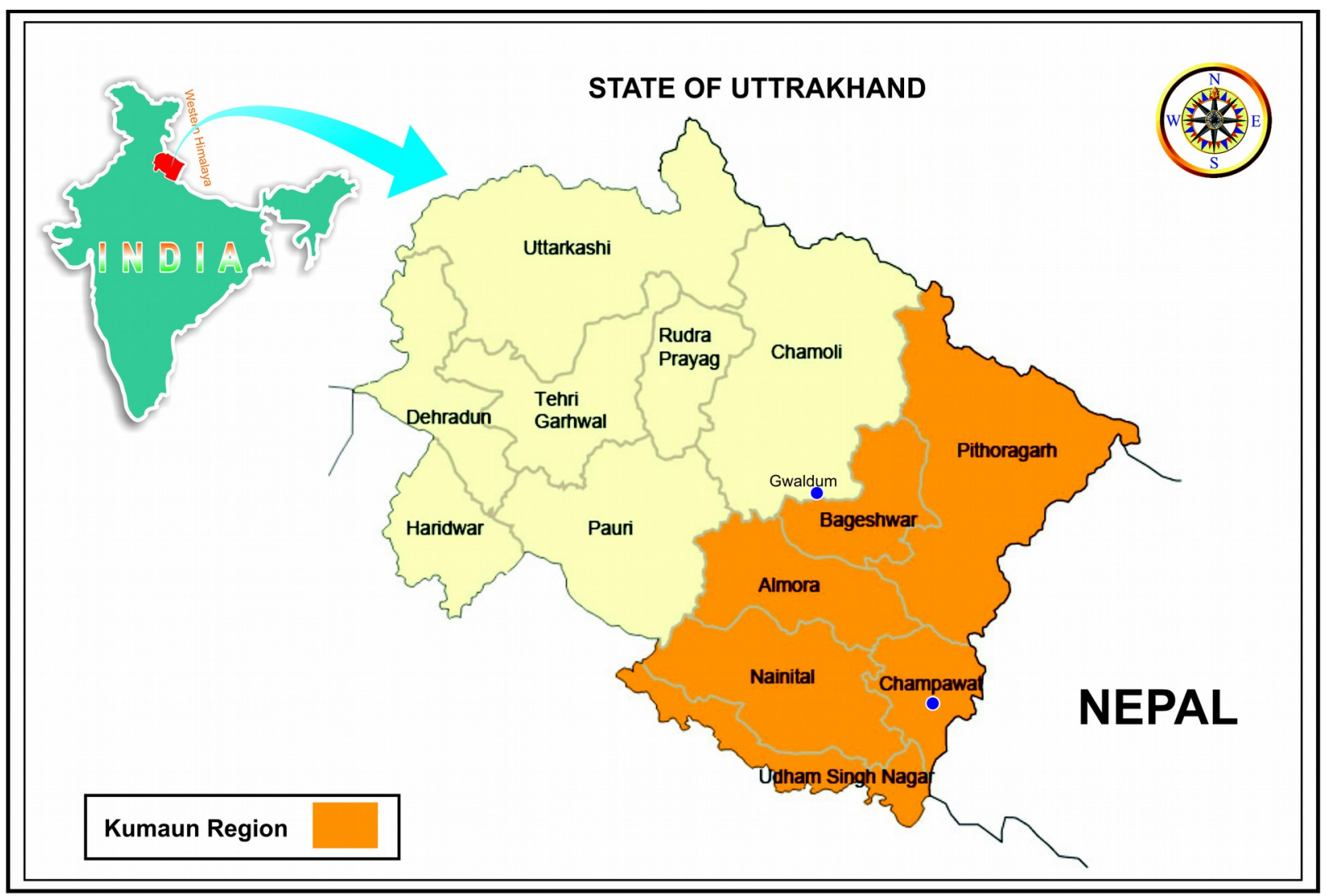

Plate 1:A Map of India showing the state of Uttarakhand in Western Himalaya and the two collection sites in Kumaun Region in State

on the stem and ending below the keel, more or less decurrent, obovate to oval, 1.0-1.8 mm long and 0.7$1.1 \mathrm{~mm}$ wide, apex subacute with a point or obtuse, margin often recurved, minutely to coarsely dentate, teeth 1-4 celled long and 1-3 celled wide at base. Marginal cells of the leaf 12-15×10-12 $\mu \mathrm{m}$, cell cavities oval to round, rarely squarish, with thickened walls and trigones, median cells 15-18×20$24 \mu \mathrm{m}$, oval to quadrate, with rather thin walls and not so large trigones, basal cells $28-32 \times 15 \mu \mathrm{m}$, cells of decurrent base up to $42 \times 12 \mu \mathrm{m}$; cuticle smooth to somewhat verrucose. Gemmae green, 18-20×10-12 $\mu \mathrm{m}, 2$ - (occasionally 1 - ) celled, borne at the margin of very young leaves.

\section{Specimens examined}

India, Western Himalaya, Uttarakhand, Kumaun Region, Champawat District, Mayavati in Lohaghat (alt. $1950 \mathrm{~m}$ ): 446 \& 458, Sept. 1977, and Abbott Mount in Lohaghat (alt. 1900 meters), H-79/21 May 1979, leg. S. N. Srivastava \& party, det. M. Rai et al. Deposited in the Duthie Herbarium of the Botany Department, University of Allahabad.

\section{Ecology \& Distribution}

The populations of this taxon were growing along with Plagiochila chinensis on the rocks which were heavily shaded in the interior of the oak (Quercus leucotrichophora) dominated forest and not on the roadside.
The species grows in pure stands on vertical cliffs under very moist and shady conditions. Sometimes, it is associated with Plagiochila chinensis.

\section{Discussion and Conclusion}

The two species of the genus, Scapania, namely, $S$. ligulata, instituted by Stephani in 1904 and $S$. stephanii, instituted by C. Müller (Now, referred as Müll. Frib.) in 1905 are purely the Asian taxa belonging to the primitive Section, Nemorosae (Müll. Frib.) H. Buch. Besides the 'type' locality Japan, the two forms are reported from Taiwan, India and China (See, Amakawa, 1964; Parihar et al., 1994; Potemkin et al., 2004; Dandotiya et al. 2007; Singh \& Nath, 2007; Srivastava \& Srivastava, 2007; and, Eshuo et al., 2012). At present, S. stephanii C. Müll., because of its similarities and overlapping traits with $S$. ligulata Steph. is treated as synonym of the latter. Potemekin et al. (2004) have, however, made a detailed study of the Chinese populations of the ligulata-stephanii complex and observed that the two taxa can be segregated on the basis of the size of the plants, size of the leaf lobes and length of the keel, and treated these distinctions at the subspecies level. They noted that "the subsp. stephanii appears to represent a complex of small forms with rather narrow and largely triangularly pointed lobes, whereas subsp. ligulata is a complex of larger forms with broader and often obtuse leaf lobes". In the light of these observations, an examination of the herbarium specimens collected from Champawat district in Kumaun Region of Western Himalaya and referred to as S. stephanii along with its 'ecotype' by Srivastava \& Srivastava (2007) was made. We found 


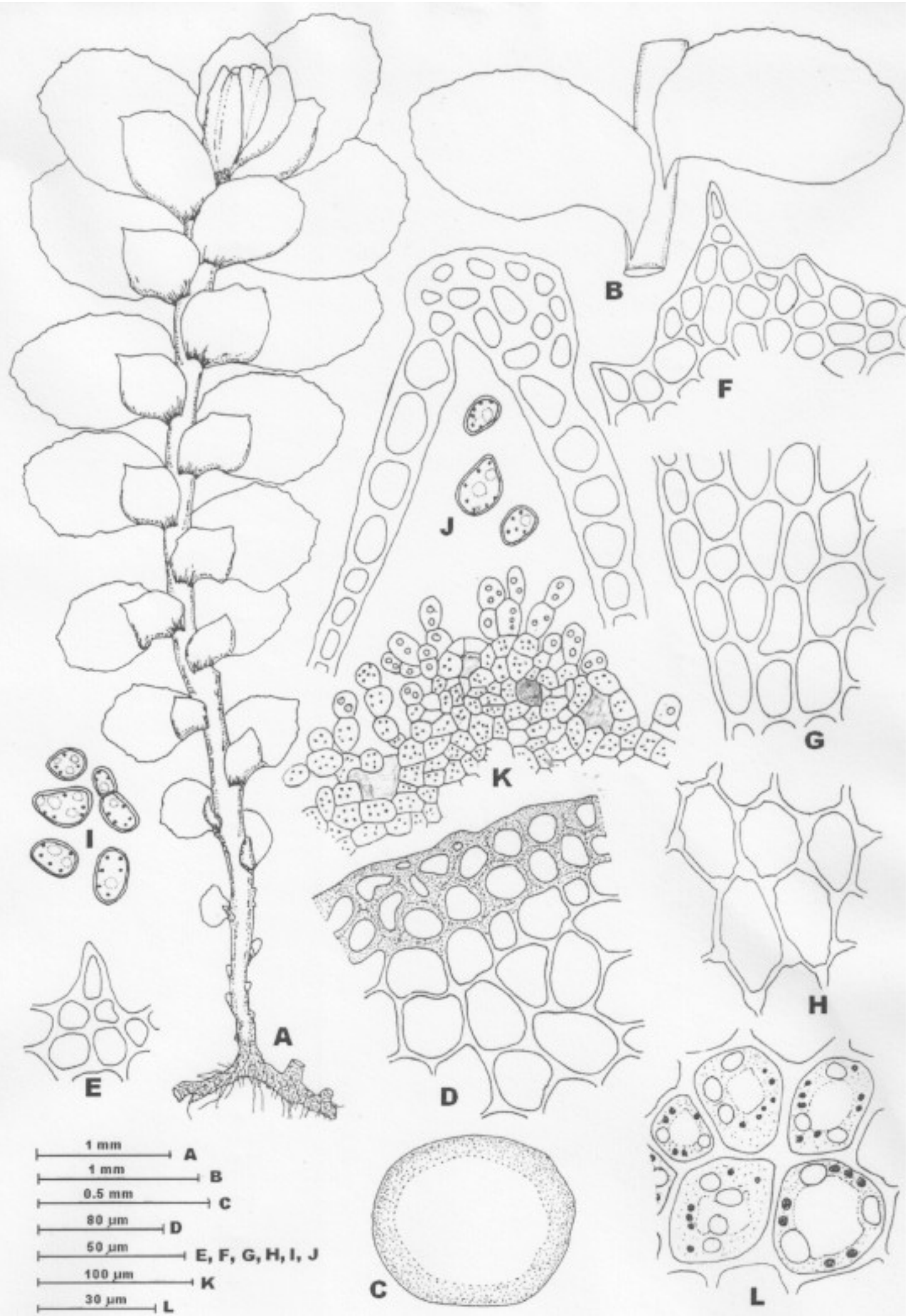

Plate 2: Scapania ligulata subsp. stephanii (Mull Frib.) Potemkin, Piippo \& T. J. Kop. (Figures A-L). A. Plant, dorsal view; B. Part of the plant, ventral view; C. Stem, t.s.; D. Part of the same magnified; E. \& F. Marginal cells and teeth of the leaf-lobule; G. Median cells of the leaf-lobule; $H$. Basal cells of the leaf-lobule; I. \& J. Gemmae; K. Margin of the young leaf-lobule with developing gemmae; L. Oil-bodies in the median cells of the leaf-lobule.

that the two forms cited by them were, in fact, $S$. ligulata subsp. ligulata and $S$. ligulata subsp. Stephanii respectively. Our recent collection of the subsp. stephanii from Gwaldam adjacent to Kumaun
Region and that of Singh \& Nath (2007) from Meghalaya in Eastern Himalaya reaffirms the fact that the subspecies is well distributed in Indian Himalaya. This is in contravention of the observation 


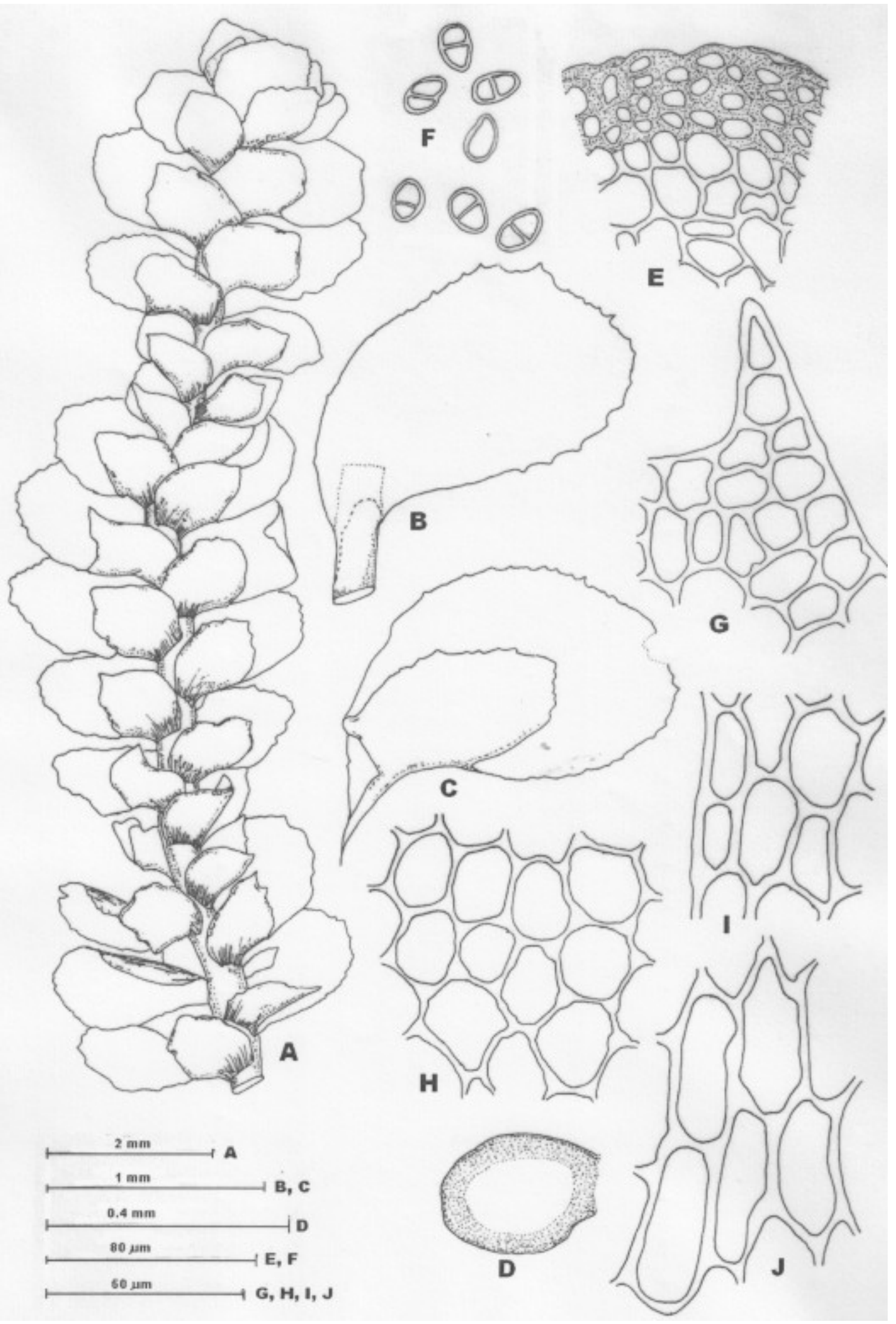

Plate 3: Scapania ligulata Steph. subsp. ligulata.( Figures A-J). A. Plant, dorsal view; B. Leaf attached on the ventral side of the stem; C. Leaf, dorsal view; D. Stem, t.s.; E. Part of the same, magnified; F. Gemmae; G. Marginal cells and tooth of the leaf-lobule; H. Median cells of the leaflobule; I. Basal marginal cells of the leaf-lobule; J. Basal cells of the leaf-lobule.

of Potemkin et al. (2004), who, while talking of radiation of the two subspecies in Chinese specimens of the ligulata - stephanii complex, stated that“...they have somewhat different distributions; subsp. stephanii is distributed further northwards than subsp. ligulata and does not penetrate into Himalaya." Nonetheless, the authors are justified when they suggest that "these complexes seem to be genetically stabilized" since the Indian specimens strongly corroborate this observation. In addition to 
the distinguishing points mentioned by them we have noted that in stem anatomy and that of gemmae the two subspecies further differ. While the subsp. stephanii has fewer layers of cortical cells (2 or occasionally 3) with lesser degree of thickening than subsp. ligulata which have more layers of cortical cells ( 3 or 4; occasionally 5) and the thickenings are more, almost bast-fiber like. Similarly, on the subject of cell number in gemma, the subsp. ligulata has predominantly 2-celled gemmae as against 1-celled gemmae in subsp. stephanii. Since 2-celled state of gemma is considered 'basal' (Potemkin, 2002) besides the large sized plants the subsp. ligulata appears to be primitive than the subsp. stephanii. So far as the morphology and number of the oil-bodies are concerned, both have large, spherical to ovoid and coarsely segmented oil-bodies which are 2-4 per cell (Singh et al. 2012).

\section{Competing Interests}

The competing interests of the present research paper include (i) the understanding of the taxonomy of the Indian specimens of ligulata-stephani complex of the genus Scapania; (ii) the confirmation of the existence of the two subspecies in the genus; and (iii) the contradiction of the statement of Potemkin (2004) about the radiation of the subspecies ligulata that it has not penetrated in the Himalayan mountain.

\section{Authors' Contributions}

MR conceptualized the idea of the research paper besides identifying the freshly collected and herbarium specimens; BKK made microscopic studies, prepared the illustrations and suggested some valuable points on species radiation; and, SNS coordinated the work, interpreted the results and drafted the manuscript after thorough discussion with other two authors. All authors read and approved the final manuscript.

\section{Acknowledgement}

We sincerely acknowledge the grant received from UGC for undertaking the present work and to Sarvesh Rai for his support during plant collection.

\section{References}

Amakawa, T. 1964. A short history of Himalayan Scapania. J Hattori Bot Lab 27:1-19.

Amakawa, T., and S. Hattori. 1954. A revision of the Japanese species of Scapaniaceae. J Hattori Bot Lab 12: $91-112$.

Dandotiya, D., H.Govindpyari, S. Suman, and Uniyal, P. L. (2007). Checklist of the bryophytes of India, Arch Bryol 19 by Jan-Peter Frahm. www.archive-forbryology.com

Eshuo K., S.K. Chaturvedi, and V. Sale. 2012. Morphotaxonomic studies on genus Scapania (Dumort.) Dumort.: Hepaticae in Nagaland, India Indian J. Fundam. Appl. Life Sci. 2(2): 42. (http://www.cibtech.org/jls.htm)

Kashyap S. R. 1932. Liverworts of the Western Himalayas and the Panjab Plain. The Chronica Botanica, New Delhi.

Parihar, N.S, B. Lal, and N. Katiyar. 1994. Hepatics and Anthocerotes of India, A new annotated checklist. Central Book Depot Allahabad.

Potemkin, A.D. 2002. Phylogenetic system and classification of the family Scapaniaceae Mig. emend. Potemkin (Hepaticae) Ann Bot Fennici 39: 309-334

Potemkin, A.D., S. Piippo, and T. Koponen. 2004: Bryophyte flora of Hunan Province, China. 4. Diplophyllaceae and Scapaniaceae (Hepaticae). Ann Bot Fennici 41: 415-427

Singh, A.P. and V. Nath. 2007. Hepaticae of Khasi and Jaintia Hills: Eastern Himalayas. Bishen Singh Mahendra Pal Singh, Dehra Dun 154-161.

Singh, D., M. Dey, and D.K. Singh. 2012. Studies on oil-bodies in some liverworts from Sikkim, Eastern Himalaya. Taiwania 57(4): 384-390.

Singh, S.K. and D.K. Singh. 2009. Hepaticae and Anthocerotae of Great Himalayan National Park and its environs (HP), India. Botanical Survey of India, Kolkata

Srivastava, S. C. and A. Srivastava. 1995. Species of Scapania from Lilum in Kumaon (Western Himalayas) Uttar Pradesh, Geophytol 24 (2): 137-145

Srivastava, S.C. and A. Srivastava. 1993: A remarkable Scapania (Scapaniaceae) from Manali (Himachal Pradesh, Western Himalayas). J Indian Bot Soc 72: 237-240

Srivastava, S.N. and P. Srivastava. 2007. Scapania stephanii K. Muell.: A hepatic new to Indian Bryoflora. Phytomorphol 57(3): 133-136. 